\title{
Geopolitics in the Western Balkans: linkages, leverages and gatekeepers
}

\author{
Prof. Asoc. Enika Abazi, Ph.D. ${ }^{1}$ \\ Director of the Paris Peace Research Institute, France \\ University of Lille, France
}

\begin{abstract}
With the end of the Cold War, Western Balkans countries have embraced the perspective of integration into the Euro-Atlantic structures, with the exception of Serbia and Bosnia-Herzegovina regarding accession in NATO. The return of international system from hegemonic to competitive followed by the ambiguities that accompany the integration into the Euro-Atlantic structures marked the return of competitors like China, Russia and Turkey in the regional affairs. To map out sources of influence and the context in which foreign interferences affect decision-making and interests, transfer ideas and norms in the region, the paper uses the concept of linkages that facilitate the understanding of opportunities and constrains, benefits and costs resulting from established relationship between Western Balkan countries and different international and regional powers. The paper makes a multi-level investigation of linkages developed between Western Balkans and the leverage of the most influential actors during the last decade, without undermining historical and societal context that favor of disfavor them.
\end{abstract}

Keywords: Western Balkans; EU; linkages; cooperation; integration; power; leverage; small power.

\section{Introduction}

Moving towards the "age of nonpolarity" (Haas 2008), a global condition of going back to the historic norms of separate multiverses, world politics is heading "back to the future" (Mearsheimer 1990). From a realist point of view, this is a period in which uncertain workings of the multipolar balancing process may bring again major wars for the same reasons as in 1914 and 1939. The situation is complex considering that the international level we are in a process of reconfiguration of power poles and zones of influences, which complicate choices of countries in Southeast Europe. A choice that gets compounded by entangled interests of different powers at regional, European and global level. After the annexation of Crimea by Russia in 2014, the order of things

\footnotetext{
${ }^{1}$ Enika Abazi (Enika.abazi@univ-lille.fr) is the Director of the Paris Peace Research Institute (France) and lecturing at the University of Lille (France). She held visiting positions at Copenhagen Peace Research Institute-COPRI (Denmark), Sciences Po Rennes (France), University of Pisa (Italy), National University Institute - IUF, (France), Bryant University, (US). She has published in outstanding academic journals such as the Cambridge Review of International Affairs, Third World Quarterly, Time and Society, Journal of Contemporary European Studies, Communist and Post-Communist Studies, Middle Eastern Studies, International Critical Thought etc.
} 
changed in Europe and elsewhere. Ironically, keeping in mind the 1856 Crimean war, it looks as big overturns in Europe always start there.

Western Balkan countries are aligning with the EU, while trying to develop economic and political linkages with other powers, looking to balance identity issues with security and economic concerns on the one hand, and regional challenges with strategic partnership choices on the other hand. As long as they are compatible, they could accommodate both political goals and state consolidation. For a detailed and perceptible account of the influence of external powers in the Western Balkans in general and Albania in particular, one needs to understand the density of ties with external actors or the "linkages", and the vulnerability to external pressures or the "leverages" that others have on domestic policies, together with the role of political elites or the "gatekeepers" that hold the key to turning up and down the weight of external pressures. In this article, the specificities of WB countries choices will be discussed by considering the effects of the regional context and the competing interactions between EU and Russia, Turkey, and China. The choice of actors is based on their potential to influence and impose changes on countries policy choices.

\section{Leverages, linkages and gatekeepers}

Linkage and leverage are two concepts developed by Levitsky and Way (2005) to investigate when and to what degree external actors impact matters for a country. ${ }^{2}$ Linkage is best defined as the "density" of economic, political, diplomatic, social, communicational and transnational civil society ties as well as "cross-border flows" of trade, investment, people and communication. Although it represents not a direct action taken by external actors, such as states or international organizations or both, the cost of failing to comply with their requirements could be with unpleasant consequences for the targeted state because of the high cost of non-action or counteractions. Effects of linkages are difficult to be measured. Yet, one can weigh the density of ties with specific external actors keeping in focus geographical proximity and/or historical affinities, and keep in mind their relative power vis-à-vis the targeted state, without undermining pressure emanating from the international power configuration in general. This pressure is supposed to be even stronger within closer and more secluded neighborhoods. The degree of density of linkages can be used to explain the success or failure of external influence.

The understanding of linkages is closely related to state vulnerabilities which can be explained in terms of leverage. Leverage is defined as the vulnerability of governments to external pressures from different external actors or the potential role that the latter

\footnotetext{
${ }^{2}$ Earlier Arthur Stein coined linkage politics as "a state's policy of making its course of action concerning a given issue contingent upon another state's behavior in a different issue area," which signify an "obvious response" to a country's own perceived "unbalanced or asymmetric decline" $(1980,62)$.
} 
can play on the fate of the ruling elites in a targeted country (Levitsky and Way 2005, 22-23). It is assumed that, if linkage is extensive, the effects of external action are most likely to be rewarded even in the absence of substantial leverage. Leverage is most effective when, in combination with linkage, is supported by strategies of pressure "including political conditionality and punitive sanctions, diplomatic pressure, and military intervention" that enable the external actor to compellingly follow up on his words, which rise significantly the cost of non-compliance for the target state (Levitsky and Way 2005, 23-25). Although linkages are structural determinants that cannot be manipulated in the short terms, domestic elites are not mere objects of external influence, as they can actively facilitate or constrain ties with external actors (Tolstrup 2009). The communist Albania case is a good example. The elite of the time had the capacity, at least for two decades, to orchestrate a complete isolation of the country and close down the influence of external actors, though with dear consequences for the development of the country and its future modernizing prospects.

The logic of linkages and leverages makes more sense to understand small states politics that is conspicuously absent from mainstream International Relations scholarship, mainly focused on large states politics. This is because a small state "tends to constitute no more than a dispensable and non-decisive increment to a primary state's total array of political and military resources and which tends to believe in its inability to rely on its own means and this is then recognized by the other states involved in international politics" (Braun 1983, 9). Besides population, wealth and political orientation that are used to weight the size of a state (Sawyer 1967), geography is also an important element that take importance in small state politics, especially if it is located in an area of strategic importance to one or more leading power (Mathisen 1971, 30-31) or it is considered as a buffer or part of a buffer zone (Jesse and Jesse 2016, 87). This is the case of the South East Europe, that represents a "shatter belt" between Europe and Asia, a colorful region where East meets West, and an area where three of the world's major religions, Christianity, Judaism and Islam have coexisted, albeit uneasily at times over the course of centuries (Treadway 1997, 20). This situation, current even today, keeps the countries of the region in the great powers agenda and their rivalry challenges the stability of the region. Of course, we may assume that small states have a policy space to operate that results on resisting by soft balancing, balking, blackmailing, and leashslipping, as they claim neutrality or accommodate regional and global hegemony by binding, bonding, and bandwagoning or following, although not always going down this path of least resistance (Williams, Lobell, and Jesse 2012, 33).

The linkage approach recently reconsidered Levitsky and Way (2005) predominantly focuses on the evaluation of the success of the democratization or the Europeanization processes in different countries, but it also can be used to look at leverages and the intensity of linkages to evaluate the role and nature of external influences and 
to understand how they have been established and transformed in function of the changing geopolitical context in the case of the Western Balkans and Albania. Hence, in this paper, the past is not detailed, but it is rather explained in the light of the imperatives of small state geopolitics. The past is used to show how the others have conveyed their interests to countries of South East Europe, but also to question the present and imagine alternative futures. In so doing, I will be able to seize the interplay of change and continuity of external influences, while comparing the linkages and leverages of external actors in the new geopolitical context and keeping a close sensibility at issues of the changing distribution of power in the region. At the end, I will evaluate to what extent Albania has capably established useful linkages, both historical and new, to gain geopolitical stability, consolidate democracy, integrate in the North-Atlantic structures and resolve its national development and identity issues. Finally, some of the reflections and insights will be discussed with the aim to generate further discussions about possible choices of small powers in complex geopolitical contexts.

\section{Vulnerabilities and linkages of a complex region}

Even though short, the 1912-1913 Balkan wars represent the most dramatic period in regional history, a time of tremendous movement, unprecedented change, and important remaining questions that still haunt South East Europe politics. After nearly five centuries of Ottoman administration, the political map of the South East Europe was temporarily defined. Balkan states joined the body politic of Europe, eager to start a new being and assert their rights. As a matter of fact, although formally independent, the Balkan states remained economically and politically weak, vulnerable to external aids and influences, and in competition with each other for state preservation, expansion and international support. Because of that, political landscape remained very fragmented.

Most of the Balkan states, are small in terms of population, territory, economic importance, military capabilities and power. After the wars, they ought to face their defeats and reconcile themselves with the loss of territories and population in most cases arbitrary, which triggered huge economic, political and social inherited problems. The anger, bitterness, fear, and resentment of lost territories remained for long an important obstacle to the establishment of a regional system based on mutual relations of a certain degree of intensity and regularity. Albania, for example proclaimed independent statehood (1912) in the midst of the Balkan wars. The newly created state was a consequence of a triple game: Great Powers rivalries for zones of influence in the South East Europe, Albanian national movement, and neighboring Balkan states prowling appetite for territories, all feeding each other's vulnerabilities and choices of alliances and cooperation partners. 
This situation prevented the development of regional functional linkages that neo-functionalists propose as a way to initiate and thereafter facilitate the settlement of sustainable peace towards much needed modernization and development (Haas 2004). Being small and poor and in the absence of a developed integrated regional system, none of the South East Europe states have been able to control or dominate the neighbors and maintain sovereignty and independence without the economic, politic or military support of outsiders. State system instability imposed linkages leading to economic and political dependency, while favoring alliances with outside powers that ensured the commitment of larger partners to mediate consultations and involvements in future emergencies, containment of enmities, defense of identity and the like (Cleveland 1970; Braun 1983).

All this gives some of the reasons for the division of the South East Europe countries into opposing power blocs in both World Wars, which emphasized rather than lessened the kinds of inherited vulnerabilities. Historically, the interests of major powers and their alliances have been sources of division rather than integration of the South East Europe. Even though more implicitly than explicitly, they often powered nationalism in the region and/or a sense of alienation or isolation (Jelavich 1983; Danopoulos and Messas 1997; Bugajsky 1994). Balkan states were encouraged and manipulated by the Great Powers in the hope of gaining influence. In this ways, "their size, shape, stage of growth and even existence were in the final analysis regulated by great powers considerations" (Pavlowitch 1999, 334).

Permanent instability allowed Great Powers to both impose the political legitimacy of preferred ruling elites and shape the size of the targeted state out of the competition between them. This way of doing things have gained consistency affecting how gaining legitimacy is perceived in most of the countries of the region even nowadays (Lampe 1990, 190). The political actor that acquires foreign support automatically become legitimate for the public. This attitude gives precedence to the external factor and undermines the domestic legitimizing procedures, showing in this way the weakness of civil society and the danger of basing legitimacy on an alien judgement that may be biased and effected by other than national interests. In return, the quest for internal legitimacy generate tensions and confrontations, threatening the social order, internal stability and prospects for democracy with severe consequences for the states of the region (Diamandouros 1994), including Albania (Doja 2001). The permanence of internal conflicts prevents a balanced social development and national integration, while straining relations with neighbors, a prominent source of continuous economic, social, and political problems (schönfeld 1990).

The Cold War did not have any positive effect in altering inherited vulnerabilities and dependency linkages. Falling under the Soviet ideological umbrella, most of the Balkan states imported totalitarianism, which was true even in the case of Greece. 
The choice of totalitarianism is not accidental, it was closely related to the inherited "sultan heritage" and other previous legacies that have left their imprint on the sociological setup of Balkan societies and elites, in which the state "successfully penetrates the day-to-day activities of most of its subject population" (Giddens 1996, 302). The maintenance of totalitarian regimes imposed the existence of a single party and a dictator that have a total monopoly over mass communications, operational weapons and social organizations, including a well-established secret police (Arendt 1974). The main characteristics of the inherited totalitarianism also favored from the elites were "the highly personal and arbitrary nature of rule and the absence of the rule of law, the unmediated and despotic exercise of power, low institutionalization, the absence of intermediary structures, and hence, the weakness of civil society" (Weber 1978, 231-232). In this way, the rigidity of the Cold War played a significant role in the consolidation of authoritarianism in the region, as it served as a means to the Soviet superpower to preserve the rigid "shatter belt" that divided the zones of influences between the West and the East (Treadway 1997).

Nevertheless, Balkan elites have tried many times to increase the range of their political independence vis-à-vis the Great Powers (Castellan 1999). Efforts to establish a Balkan Federation (1947), a new Balkan Pact (1954) or a Balkan Nuclear-Free-Zone (1957) stand up to the interferences of the Great Powers in the region, even though all failed at the end. Also, the Albanian communist leadership tried alignment with the Warsaw Pact and China, even though Albania immersed itself in total isolation afterwards. Yugoslavia choose to lead the non-alignment movement, while other South East Europe countries split between the Warsaw Pact and NATO, but the balancing efforts of the superpowers unfortunately helped the preservation of the existing regimes and state system in the Balkans (Brown 1987; Treadway 1997, 19). Internally, the authoritarian rule of military juntas or communist parties constrained nationalism as a way to preserve established borders, even though without managing to resolve or settle it. It may even have implicitly encouraged a sort of "constitutional nationalism" that later became a source of conflict in Yugoslavia (Hayden 1992).

The peoples of the region met the new post-Cold War challenges by willingness to abide by democratic rules. Democracy provided not only for peaceful relations. Democratic procedures of public participation provided also a window of opportunity for re-nationalization of national policies. Most South East European countries formalized election processes after the demise of communism, but as non-consolidated democracies, they eventually subverted democracy to adopt radical politics (Doja 2001). In the beginning of 1990s, much needed advancement of industrialization and modernization was undermined by hyper-nationalism, which was not a response to people's demands, but an elite-driven, politically motivated strategy to legitimize power by obtaining popular support through appeals to ethnic nationalism (Nevers 1993, 71; Gagnon 2004). An intensification of the disputes had a 
domino effect throughout Yugoslavia, exacerbating security considerations for other countries of the region, especially in Albania with half of its ethnic population living in Montenegro, Macedonia and Kosovo (Brzezinski 1989; Larrabee 1990). Both ethnic and state nationalism have worked to invent a homogenized past in attempts to address a heterogeneous present and construct ongoing political crisis in the region that still constrain elite choices and undermine democratizing leverages. Ultimately, the advent of what is called democracy in Albania and elsewhere in the South East European countries was hampered by the lack of pluralistic political culture and civil society, the unfamiliarity with the workings of market economy, the vacuum in constitutionalism and obedience to the rule of law, and the non-respect of human and minority rights (Doja 2001).

Albania as all the countries of the region, except Greece to a certain degree, did not only suffer from the lack of a democratic culture, effective government and control of corruption. Albania and the region face grave economic structural problems, connectivity in and out the region, small size of the market, lack of technological infrastructure, and the like. This are some of the challenges that countries of the region, try to address, because it affects its dependency on others, threatens the stability and modernization of the country, the power calculations of the elites and the everyday life of the citizens.

The first radical economic reforms aimed at introducing a fully-fledged market economy in the Balkans started already in Yugoslavia by the end of 1980 s and in Albania in 1991. Despite the wide variety of individual rankings regarding different indicators of the modernization and development performance of a country, there is a high degree of convergence of the institutional, political and economic characteristics of the Western Balkans countries as a whole, which leaves no point to isolate Albania as a different case. The outcome of twenty-five years of transition in the Western Balkans show they still have not managed to establish a sustainable growth. By 2008 only three countries (Albania, Croatia, and Macedonia) had surpassed their 1989 real GDP level, while Montenegro was still at 92 percent, Bosnia and Herzegovina at 84 percent, and Serbia at only 72 percent of the GDP produced in 1989. Remarkably, by 2013 Albania surpassed its 1989 real GDP by some 80 percent, the reasons being its much lower level of development in 1989 and its non-involvement in the recent Balkan wars (Estrin and Uvalic 2016).

Following recent recessions caused by the global and eurozone crises, most countries have experienced a further setback. Western Balkan countries are today the poorest economies in Europe. In 2016, a GDP per capita (at purchasing power standards) is at 13 percent of the EU-28 average for Albania for example (Estrin and Uvalic 2016). Moreover, the Western Balkans have also experienced a strong reduction of FDI and other capital inflows after late 2008 (Bartlett and Prica 2012). Empirical analysis indicates 
that relevant FDI inflows that could have contributed to economic growth and welfare in the host country via capital accumulation have had almost no significant impact on manufacturing value-added, employment and exports of the Western Balkan countries in the decade of 2002-2012. The reasons of this stagnation that mainly shape Western Balkan handicaps can be attributed to the choice of the "growth model" in transition economies (Becker and al 2010), policy-makers perceptions (Demekas et al. 2005), size and level of development and geographical position (Estrin and Uvalic 2014), lack of scale economies (Kalotay 2010), together with unsettled political issues and stability. Thus, microeconomic, macroeconomic and institutional reforms may be a necessary condition to attract FDI, but are likely not to be sufficient (Moran 2014, 5).

European accession may promise to address these challenges, because it is supposed to trigger foreign direct investments on plus of aid funds. However, Western Balkan vulnerabilities show linkages, leverages and elite choices, as well as the importance of geography and historical references within the current geopolitical dynamics. After years of economic crisis and stagnation, the vulnerability of Western Balkan governments is high. With EU project on jeopardy, new linkages to Russia, Turkey, China and Gulf Arab countries are gaining strength, opting to change the existing configuration of leverages and linkages. A closer look at the leverages and linkages could help better understand the available answers.

\section{EU Enlargement a linkage in flux}

On March 25, the Council of the European Union gave the green light to the opening of the access negotiations for Albania and North Macedonia after a long period of refusals for both countries. After that, other measures like 750-billioneuro recovery plan, known as Next Generation EU, was forwarded in July 2020. The decision was deliberately strategic, a "strong and clear message not only for the two countries but for the Western Balkans as a whole", confirming "the geostrategic importance of the Western Balkans" and "the European Union's geostrategic interest" (European Commission 2020, 25 March). ${ }^{3}$ The decision is perceived as an important step in re-engaging in the region more actively, still dependent on rigorous positive and negative conditionality and reversibility of the process. As new as it may sound, the geopolitics importance of the Western Balkans Six was recognized explicitly two years ago by the EU recent strategy of the European Commission: "A credible enlargement perspective for and enhanced EU engagement with the Western Balkans" (2018). At that time, as in 2020, there are fears that the Balkans could easily "become one of the chessboards where the big power game can be played" (Mogherini 6 March 2017). Despite

\footnotetext{
${ }^{3}$ The decision was backed up by a package of aid for all the countries of the Wester Balkans Six, after criticism for lack of solidarity. Brussels announced 40-million-euro aid to help WB6, 15 to Serbia, four million to Albania and North Macedonia, five million to Kosovo, seven million to Bosnia-Herzegovina and three million to Montenegro. 374 million will be allocated to help cushion the economic impact of the epidemic. WB countries will also be allowed to take part in an EU joint procurement program to buy protective medical equipment (EURACTIV 2020, 30 March).
} 
concerns, the EU failed to provide a functional common strategy for the region, instead it offers frequently the definition/redefinition of the region and introduce procedural changes of the accession process.

In the EU official documents, the region is coined as Balkans in the broad sense, the South-East Europe in a "de-balkanizing" logic, and then as Western Balkans which designates all the countries currently awaiting accession to the EU in the region, to the last label Western Balkans Six clustering the countries of the region left outside the Union. While, they coexist without having any real ascendancy in different EU documents and discourses (Cattaruzza 2008), they hide different political projects that in the past different Member States gatekeepers have labelled to mark their intentions and interests (Todorova 1997, 28; Abazi and Doja 2016; 2017, 1014; Abazi 2019). The definition is not simply a question of naming; it is a clear indicator of both EU's interest in the region and its ambiguity on how to pursue.

In this circumstance is worth reminding Germany's premature recognition of Slovenian and Croatian secession from Yugoslavia (1991) that accelerated the forceful dissolution of the Yugoslav Federation. The resentment of the increasing US influence pined by Dayton Agreement (1995), that provoked the French initiated Royaumont Process focusing on the promotion of Stability and Good Neighborliness in South-Eastern Europe (1995), later supplemented by German presidency initiative on the South-East European Stability Pact (1999) aimed at strengthening peace, democracy, human rights and economy in the countries of the region. The Pact was aimed to confirm the EU "irretrievably committed to becoming a Balkan power with specific responsibilities and interests" (European Parliament 30 April, 1998). In this sense, the last enlargement decision offers no surprises. The enlargement towards WB6 is for the EU not only an external policy situation aiming at creating a stable neighborhood. It is mainly an internal, intraEuropean problem, because much in EU politics depends on the multipolar model of power balance of Member States (MS) within EU institutional structures, which undermines the enlargement policy as well as its relevance and effectiveness. It can be argued that EU has the external capacity to prepare WB6 for membership and the internal institutional capacity to integrate them (Börzel, Dimitrova, and Schimmelfennig 2017). This is even more evident if we consider that the Western Balkans collectively could bring only a 3.2 percent increase in the Union population and 1.3 percent increase of GDP for the EU27 (Marazopoulos 2013, 216). Yet, under the banner of "fatigue", the conflict of interests between EU member states or imperatives of domestic politics are often conveyed as a question of either deepening enlargement or containment, which becomes an object of contention within the Union, leading to incompatible positions and disruptive practices that minimize its leverage in the region (Doja and Abazi 2021).

The debates on EU widening or deepening integration is marked by a new reflection on the future of Europe, initiated with the publication of the EU's White Paper on the 
Future of Europe in March 2017, followed by President Macron's speeches in Athens, la Sorbonne, Strasbourg and Aix-la-Chapelle, supported by the non-paper shared with EU member states by French presidency in autumn 2019. The non-paper demands a "renewed approach" in the enlargement process of the Western Balkans countries. The French non-paper proposes a shift from a chapter-by-chapter accession process with a seven-stage process. The process would entail convergence with EU norms and standards and would not be unidirectional. If a candidate country's government backslides, the EU can reverse the process. Beside changing the methodology of the accession process of candidate countries in the middle of the process, in practice it means blocking opening of accession negotiations with North Macedonia and Albania, although Germany, Austria and Visegrad countries opted for the yes option. This is a change in a long row of modifications in enlargement methodology for the WB countries integration, changes that include Copenhagen-plus criteria, and Stabilization and Association Process. This decision seems to blow the credibility of the EU in its closest neighborhood by weakening the influence of the Union vis-à-vis the countries concerned, which will worsen levels of corruption and will cause a further setback in democratic reforms and low public support (Fouéré 29 October 2019). Already, EU enlargement fatigue has left the place to the weariness of public patience. In Albania, which is considered the most Europe loving country in the continent, the support to European integration has slowly but steadily decreasing. Based on longitudinal data of annual surveys by the Institute of International Studies since 2006, the support of Albanian public to EU integration has been almost unanimous, reaching in 2008 up to $95 \%$ (Abazi, Rakipi, and Hyseni 2008). After 2010, the support fluctuated between $85 \%$ and nearly 77\% before the candidate status was granted in June 2014 (Alls 2014, 35-36). Regardless the EU justifications for blocking the opening of negotiations, the process depends on the varying degree of preference heterogeneity among key EU member states across time.

However, with the last immigration crisis, the threat of uncontrolled flows coming from the East made EU highly dependent on the cooperation with Western Balkan on issues of security and control of boarders, and consequently security overshadows other concerns such as corruption, rule of law or freedom of media in the countries of the region. The situation as it is observed and reported in the last strategic document of the European Commission (2018) reveals a democratic backslide and stagnation in the Western Balkans Six countries. The geostrategic importance of the region, refugee crisis in combination with the need to support pro-European leaders has however weakened the strength of political conditionality as an influential linkage, some would even say that it has been counterproductive, as authoritarian rulers have gained ground against moderate leaders (Bieber 2018).

In these circumstances, the conditionality is failing to produce the expected outcomes and the reasons are deep-rooted. According to the observations of Richter and 
Wunsch (2020) the pressure for the liberalization of markets in the Western Balkans in the absence of a comprehensive legal framework allowed a small economic elite to realize private gains and build powerful networks that influence political decisionmaking. Moreover, the strong top-down conditionality has stifled domestic deliberation and weakens internal mechanisms of accountability, allowing ruling elites to easily silence domestic opponents. And last but not least, progress towards EU membership and frequent interactions with high-ranking EU and member state officials serve to legitimize ruling elites, causing stagnation of political power. As a result, the countries of the Western Balkans are stuck in a 'state capture trap' that leads to stagnating democratization and the inability to implement deep reforms.

It is not the first time that the politics of enlargement, old and new, find EU squeezed in a twisted dilemma of either opening negotiation before standards or standards before negotiations. Keeping standards first would mean christening countries fatigue, haunted by the Copenhagen criteria, add-ons, Europeanization and ambiguity in the definition and redefinition of a region which have variated since the 1990s according to pragmatic political criteria and recently by the COVID 19 crisis. Favoring negotiations seems to be a precondition to keep WB6 from turning their backs on Europe and moving towards authoritarian powers that do not currently uphold EU values. Already, EU is trying to compete in the region with a "civilizational challenger" like China (Bastian 2017), whose ultimate aim is to make Eurasia an economic and trading area to rival the transatlantic one (The Economist 15 May 2017), a "spoiler power" like Russia trying to derail Balkan countries from joining Western institutions (Cappello 05 April 2017), and a "regional power" like Turkey that is significantly stronger than its Balkan neighbors and is looking to translate this strength into influence (Economist 21 January 2016; Janjevic 2017).

EU dilemma on widening or deepening integration followed by ambiguity in the mechanisms to anticipate and alleviate negative consequences of geopolitical developments and the democratic backslide in the region make one think that both sides seem falling for the prisoner's dilemma, the notorious paradox in game theory in which two parties act out of individual self-interests and both lose out in the process.

A closer look at the growing external challenges facing existing EU-WB linkages may shed some light on the exposure of the region.

\section{The 'rise of the others" ${ }^{4}$ is real}

Enlargement decisions combined with COVID 19 crisis and its handling, more than anything else, is highlighting and reinforcing the basic features of new geopolitics in all levels, and the case of the Western Balkans is no exception. On the one hand, new rising powers are inserting themselves in the region jeopardizing EU

${ }^{4}$ As proposed by Fareed Zakaria (2008, 12 March) 
linkages of the EU by assisting distressed national governments with much needed humanitarian aids. The response of the countries of the region was chilly. Serbian President Aleksandar Vucic was the first to prize China's aid while disparaging the European approach on the same remark. For him: "European solidarity does not exist... that was a fairy tale on the paper. The only country that can help us in this hard situation is the People's Republic of China. To the rest of them, thanks for nothing" (Xinhua 2020, March 17; SGTN2020,17 March). At the same time, Albanian Prime Minister Edi Rama, declared that Albania's "plan C" "if the world is upside down" is Turkey, which is committed to meeting the critical health needs of the country (Dita2020,22March). Next in the line of thanksgivings was President of Montenegro Milo Đukanović, showing gratitude to the President of Turkey, Erdogan for the health aid (Đukanović 2020, 8 April). Russia, too, looks set to help the Balkan states. Like China and Turkey it is stepping in to replace the faltering EU, flying in among other aids doctors and equipment to Serbia by 11 military planes (Reuters 2020, 3 April).

Mainly because of the close linkages developed with the Western Balkans Six countries, until recently the EU has so far not perceived the "rise of the rest" (Zakaria 2008, 12 March) as a danger to its own interests. Regardless of EU investments and assistance WB6 remain among the poorest in Europe, while representing a total regional population of less than 18 million and according to the data of IMF an average per capita gross domestic product of little more than $\$ 6,000$, only 14 percent of the EU incomes $(\$ 44,467)$. With unemployment rates at an average of 20 percent. The entire region taken together according to UNCTAD data attracts less than 0.57 percent of the world foreign direct investment ( $\$ 10$ billion in 2018), despite its proximity with the EU, one of the most attractive markets in the global economy with 25 percent of global FDI, and at the same time one of the main investors in the world economy, with 30 percent of the investment.

While WB6 European membership remained unclear because of the difficulties in the EU decision-making structure and heterogeneous national interests of the Member States, China, Russia and Turkey work to advance their interests in the region, the gatekeepers of the WB 6 make efforts to turn geopolitical challenges into political benefits. It helps to recall what was stated only four years ago by one of the leaders of the WB6 countries. In December 2017, during a conference organized by Friends of Europe, Albanian Prime Minister Edi Rama states in his quality of Albania's gatekeeper: "Russia and China have many things to offer. Russia can give you power energy for the rest of your life if you give up the rule of law. It is not quite uninteresting... China has the luxury to plan for the next 100 years. I would not say they have nothing to offer. And then there is also radical Islam. In our region, we are multiethnic, multi-religious. If the EU will not run to catch us, believe me, many multi-problems can restart and then it will be much more costly to marry with us later" (Rama 5 December 2017). One can sense that political 
doubletalk is deliberate. The speech is not so much intended to deceive as to use the created geopolitical leverage to haste decisions that would favor his political pledge to preserve his political power in the next elections. EU is in a certain hazel coming from a believed return of the Cold War in the Balkans, while Rama hopes to succeed by tapping into it (Wood 2017, 18 April). This speech can be highly challenging, especially when the Russians, Chinese and Turks in search of zones of influence are investing in the Western Balkans and using Coronavirus diplomacy for either geopolitical gain or domestic advantages vis à vis the other political actors. Soon after this speech, the efforts to introduce a hasty strategy for the WB6 to mild out Russia, China, and Turkey's influences into the WB6, did gain ground (European Commission 2018). "Flexibility" has been the preferred euphemism for a concerted effort to water down the previous cautious attitude. The geopolitical breeze was already blowing in favor of those who wanted the opening of the negotiations with Albania and North Macedonia.

EU enlargement to which European leaders tether their hopes for preserving the existing balance of interests in the $W B$, is undermined by the fact that politics nowadays are exposed to a severe anarchy of the global order, which may bring important geopolitical shifts in existing linkages. Furthermore, US American pursuit of a smaller role in the world under Trump administration created a vacuum that Russia is increasingly exploiting to extend its spheres of influence in the Western Balkans using its favorable linkages with Slavic and Eastern Orthodox communities. For the same reasons, Turkey is also using the so-called gönül coğrafyası (geographies of heart) to culturally extend its role on former Ottoman territories in the region, back up the minorities left from the empire with investments of economic actors in strategic sectors such as communication, infrastructure, and banking. China is also lending, investing and enhancing trade cooperation with the region, which is still characterized by major economic hurdles and political challenges. The "Chinese wisdom" and "Chinese approach", is offered as an alternative to Western democracy and "a new option for other countries" to solve their problems (Jinping 2017, 9). While Russia and Turkey are promoting military, economic, cultural and religious linkages depending on targeted states, China's influence in the Balkans is acting with the soft power of a "charm offensive" (Poggetti 2017, 24 April), mostly based on economic and trade penetration and development of dependency linkages.

Historically, the Western Balkans, represent an area where Russia and Turkey are longtime actors with their own interests and agendas reasserted in the region for some time. Unlike Russia and Turkey, China's plans for the region are more ambitious. China is claiming a global leadership role by increasing investment in the types of assets that established EU as a normative power and set US leadership and authority for the second part of the last century, like foreign aid, humanitarian interventions, contributing to UN peacekeeping forces, and joining international initiatives to address global problems 
such as environmental global threat, terrorism, piracy, nuclear proliferation (Osnos 2018) and recently COVID 19 crisis. In the framework of integrating the 17+1 initiative into the platform of the Belt and Road Initiative, China is working full steam on institutionalizing cooperation with each of the Southeast European countries, in order to use the region as a gateway and transit commercial platform to EU market. China leverage seems to be a charming "soft power" offensive, mostly based on economic, infrastructure and trade penetration leading to dependency linkages. The so called "Chinese wisdom" or "Chinese approach" comes as an alternative to Western democracy, "a new option for other countries" to solve their development problems (Jinping 2017, 9). Chinese approach does not engage in the domestic affairs of the country and gives little consideration to the nature of the regime and government. It favors economic and trade interests while showing political pragmatism. China pursues investments and is often able to come in as an investment alternative in a country in desperate need of foreign capital for its modernization.

Western Balkans EU membership perspective seems to have encouraged China to start working full steam on institutionalizing cooperation in the framework of $17+1$ initiative, which is now integrated into its platform of Belt and Road Initiative. Chinese capital and infrastructure projects represent a tempting market proposition for WB and a potential platform for China to leverage its growing economic and political influence in Europe (Poggetti 2017, 24 April). In the case of Albania, China has become in 2017 the second Albanian trading partner with 7.1 percent of the total trade, leaving behind old-time partners like Greece and Turkey, though well behind the EU trade (67.5\%) (Trade 2017). China ambition to control WB strategic sectors and extractive industries, such as petroleum and chromium, road, air, and sea infrastructures, as well as agriculture, seems growing in pace, also for the reason that the countries of the region after so many years of EU prompted reforms, still continue to be many years behind EU member states. In 2015, WB countries' GDP per capita (in Purchasing Power Standards) ranged from around 26 percent in Kosovo to 41 percent in Montenegro of the EU28 average. The gap in the level of development between Serbia and the EU has recently even widened, since Serbia's GDP per capita fell from 38 percent in 2013 to 36 percent in 2015 of the EU28 average (Milica 2019, 12). Moreover, after late 2008, due to the global financial crisis WB have also experienced a strong reduction of FDI and other capital inflows (Bartlett and Prica 2012). In these conditions, China investments promise development. China is engaged on the construction of a thermal coal plant in the city of Tuzla, Bosnia-Herzegovian, in Montenegro, Chinese firms are constructing a $\$ 1.5$ billion cross-country highway that has caused the country's debt to skyrocket to 80 percent of GDP (Mujanović and Montgomery 31 October 2019). While the EU adjustment funds for development and structural and economic change would come only if WB countries becomes full EU member. Ironically, WB countries cannot be member without having transformed their economy. In this respect, China investments are 
both an opportunity and a challenge. Being state-backed or state-owned, most of Chinese companies adopt streamlined procurement procedures that facilitate their penetration in the WB market and the money they bring is tempting and potentially promising. Yet, the infrastructure projects and lending agreements burden the government with large debt obligations. Despite promises and perspectives, it remains to be seen if these investments will bring serious technological development and not just adjustment to increase profits, or an increase in environmental pollution and no increase in employment as most Chinese companies import their own labor from China and serve as proxies for the Chinese government (Bastian 2017). Obviously, the European Commission finds "in the last decade, China's economic power and political influence have grown with unprecedented scale and speed, reflecting its ambitions to become a leading global power" 5 .

It has become clear that Russia venture to seize every opportunity to pursue his grand design of rewriting the Balkan order in Russian characters. For (Bechev 2017) there are three areas in which Russia wields influence in southeast Europe: military capabilities, energy politics and soft power. More than embracing Pan Slavism and the alleged bond of kinship with the South Slavic to settle its presence in the Balkans, Russia preys on weaknesses like pervasive corruption in the region to serve its interests, as the authoritarian Balkan politicians have exploited this causing anxiety among EU and NATO officials who then legitimated the former by countering Russia.

The role of Russia have moved from party in conflict management in the 1990 and early 2000 , by aligning with the West in many contentious issues (Abazi 2002, 2008) in the region, such as voting in favor of trade embargo in Yugoslavia in UN (1992), participating in the London Peace Conference on Yugoslavia (1992), deploying 1000 peace keepers in Croatia as part of UNPROFOR (1992-95), being part of Contact Group alongside France, Germany, UK and US (1994), sending 1200 peacekeepers in Bosnia and Herzegovina as part of SFOR, and 3150 peacekeepers in Kosovo as part of KFOR, while sponsoring with other UNSC permanent members (China abstained) the resolution 1244 on Kosovo (1999) that marked the end of fighting and establishment of an international interim government in Kosovo (UNMIK). From 2003, Russia follows with the strategy of economic expansion in the strategic sectors of different countries of WB, marked by acquisition of oil factory in Serbia (2003), aluminum factory in Montenegro (2005), oil refinery and lubricant plat in Bosnia and Herzegovina (2008), heat production and supply in North Macedonia (2012), and since 2012 entering WB banking sector. The most disturbing is the challenge Russia is bringing to established order in the WB, by trying to offer e substitute for already established institutions, such as the creation of Russian-Serbian Humanitarian Center in Nish, Serbia (2012), absenting from extending EUFOR in Bosnia and Herzegovina, or sponsoring the political coup in

${ }^{5}$ European Commission, "EU-China - A strategic outlook", 2019 (pg: 1), https://ec.europa.eu/commission/sites/beta-political/ files/communication-eu-china-a-strategic-outlook.pdf 
Montenegro (2016) followed by cyber-attacks different in Montenegro and Kosovo mainly (2016-17), or support of violent protests in North Macedonia (Secrieru 2019).

Moscow's efforts in the military field in the Western Balkans focus primarily on Serbia, which together with the Republika Srpska has joined the Collective Security Treaty Organization (CSTO) military alliance in 2013 as observer and participates in military exercises with Russia and other CSTO partners-most recently the Russian-SerbianBelarusian "Slavic Brotherhood" military exercise in July 2018. Moscow and Belgrade signed a military technical assistance agreement in 2016 to support Serbia's military modernization program, by upgrading and replacing its Yugoslav-era military stocks with used MiG-29 fighter jets, T-72 tanks, and combat patrol vehicles donated by Russia or Belarus (Stronski and Himes 2019).

The most serious is Russia robust campaign to increase its influence in the WB6, through interferences in the cyberspace, funding, and disinformation to influence political parties and voting constituencies in different countries of the region. Moscow is trying to sow confusion and distrust and help advance its interests without having to resort to conflict (Cappello 05 April 2017). Sputnik based in Serbia since 2014, has opened a section in Tirana, providing pretty much all defense and security news to mainstream media (Cappello 2017, 13 October). Most of Russia's growing sway is unseen by the public and difficult to be witnessed that makes the interference spookier. The target of these operations are geared toward slowing down and even preventing EU or NATO enlargement in the Western Balkans, as the region is one of the last in Europe not yet fully integrated into Euro-Atlantic structures.

In the 2010s, the rapid economic growth enabled Turkey to strengthen its linkages with Western Balkan countries in more ambitious and assertive way. Ankara has been always a balancing actor in the Balkans preventing the creation of a Serb-Orthodox axis that may block Turkey's way to Europe placing Russia back in an advantageous position and jeopardizing its economic and security interests. These calculations pushed Turkey to recognize the independence of Kosovo, even though risky parallels could be drawn with the Kurdish question (Abazi 2008, 2002). Turkish security leverage on the Albanian or Kosovo security field is tangled recently as Turkey is aligning with Russia on different foreign policy, security and economic issues, while Albania, is looking to advance with EU membership and is following EU and NATO policies regarding Russia.

Turkey is the an important commercial partner for most of the Western Balkan countries (Trade 2017) and an important source of foreign direct investments from several public and private enterprises in strategic sectors such as communication, infrastructure, and banking. For example at the end of 2017, Turkish total direct investments in Albania reached 2.7 billion euros (Yoruk 2008, 16 April). Nevertheless, Turkish FDI outflows are still insignificant compared to the investments from EU28 and individual member states (Trading Economics 2018). 
Turkey proposes an alternative development model to the Western Balkan countries, once part of the Ottoman Empire. However, the model of millet coexistence is proposed as a "complementary" rather than "competitive" to the European Union integration policy (Davutoglu 2008). Following this course, Turkey has launched various Balkan initiatives for participation in newly established structures. ${ }^{6}$ It established a visa-free regime and signed a free-trade agreement, as part of a Turkish style Schengen and economic community area in the Western Balkans. In fact, the idea is similar to EU Neighbourhood Policy. Up till now, many observers consider that Turkish policies show how the Europeanisation discourse is used as an instrument to establish it as primus inter pares. Without the European anchor Turkish leaders would not be in a position to promote Turkey as an example and call on countries of the region to rally around it (Demirtas 2015, 9).

Turkey is extensively investing in the societal field. TIKA ${ }^{7}$ and Diyanet ${ }^{8}$, projects, Yunus Emre Cultural Centers, Turkish education institutions and Turkish soap operas have extensively contributed to a kind of re-consideration of the Ottoman period and exposed and popularized Turkish culture and contemporary way of life. They have promoted the image of Turks as a modern people countering the traditional awkward image previously widespread in the region through history textbooks, which represented the Ottoman yoke as ruthless and responsible of countries backwardness. The other issue raising concerns is the question of whether Russian, Turkish and Chinese activities in the region will lead them to buy influence at the political level, which may challenge seriously the EU investment and maybe its cohesion. In fact, the other powers have been quietly gaining ground for years in the WB6.

\section{Conclusions}

For more than a decade, EU integration and the model of development that comes with it seems to be in competition with a "civilizational challenger" (Bastian 2017),or "systemic challenger" like China (The Economist 2017, 15 May); a "spoiler power" like Russia (Cappello 05 April 2017); a growing "regional power" like Turkey (Janjevic 2017; Gadis 2018, 28 January). The challenges to the EU project in the Western Balkans are even bigger, at least in the short term, considering Beijing, Moscow, and Ankara's tacit agreement to sidestep any suggestion of undermining each other's initiatives with competing projects. Believing that these geopolitical challenges can be solved by offering an ambiguous European enlargement proposal is magical thinking. This experiment has run its course longue ago.

\footnotetext{
${ }^{6}$ Such as South East European Cooperation Process, the Regional Cooperation Council, Southeast European Cooperative Initiative, Peace Implementation Council, and South-Eastern Europe Brigade and recently supporting the Western Balkans Fund Secretariat in Tirana.

${ }^{7}$ Turkish Cooperation and Coordination Agency

${ }^{8}$ Turkish Directorate of Religious Affairs.
} 
EU recent move is not a temporary rupture in an otherwise stable equilibrium. A more fragmented region is coming into being that in some ways maybe more flexible and open to opportunities. Especially now that autocracies promote vigorously alternative economic and "civilizational" models, using all means at their disposal, from investments soft power to coercion, this could destabilize the neighborhoods and/or challenge Western hegemonic linkages.

\section{Bibliography}

1. Abazi, Enika. 2002. "Kosovo Conflict and the Post-Cold War Order: Russia and Turkey Policies." Turkish Review of Balkan Studies 7:217-236.

2. Abazi, Enika. 2008. "A New Power Play in the Balkans: Kosovo's Independence." Insight Turkey 10 (2):67-80.

3. Abazi, Enika. 2019. "Albania: New Geopolitics and Shifting Linkages." In The Western Balkans in the World: Linkages and Relations with External Actors, edited by Florian Bieber and Nikolaos Tzifakis, 164-183. London: Routledge.

4. Abazi, Enika, and Albert Doja. 2016. "International representations of Balkan wars: a socio-anthropological account in international relations perspective." Cambridge Review of International Affairs 29 (2):581-610. doi: 10.1080/09557571.2015.1118998.

5. Abazi, Enika, and Albert Doja. 2017. "The past in the present: time and narrative of Balkan wars in media industry and international politics." Third World Quarterly 38 (4):1012-1042. doi: 10.1080/01436597.2016.1191345.

6. Abazi, Enika, Albert Rakipi, and Dorarta Hyseni. 2008. Albania and European Union: Rethinking EU Integration, http://www.houseofeurope.org/pdf/ Perceptions_2008.pdf. Tirana: AllS.

7. AllS. 2014. The European Perspective of Albania: Perceptions and Realities. Tirana: AllS press.

8. Arendt, Hannah. 1974. The Origins of Totalitarianism. New York: Houghton Mifflin Harcourt.

9. Bartlett, Will, and Ivana Prica. 2012. The Variable Impact of the Global Economic Crisis in South East Europe, LSEE Papers. London: LSE European Institute.

10. Bastian, Jens. 2017. The potential for growth through Chinese infrastructure investments in Central and South-Eastern Europe along the "Balkan Silk Road", www.ebrd.com/documents/policy/the-balkan-silk-road.pdf, European Bank for Construction and Development. London.

11. Bechev, Dimitar. 2017. Rival Power: Russia in Southeast Europe. New Haven: Yale University Press. 
12. Becker, Torbjörn, and Dăianu Daniel et al. 2010. Whither growth in central and eastern Europe? Policy lessons for an integrated Europe. Vol. 11, Bruegel Blueprint Series. Bruxelles.

13. Bieber, Florian. 2018. "Patterns of competitive authoritarianism in the Western Balkans." East European Politics 34 (3):337-354. doi: 10.1080/21599165.2018.1490272.

14. Börzel, Tanja A., Antoaneta Dimitrova, and Frank Schimmelfennig. 2017. "European Union enlargement and integration capacity: concepts, findings, and policy implications." Journal of European Public Policy 24 (2):157-176. doi: 10.1080/13501763.2016.1265576.

15. Braun, Aurel. 1983. Small-State Security in the Balkans. London: Palgrave Macmillan.

16. Brown, James F. 1987. "The East European Setting." In In Eroding Empire: Western Relations with Eastern Europe, edited by Lincoln Gordon, 8-38. Washington, D.C.: Brookings Institution.

17. Brzezinski, Zbigniew. 1989. "Post-Communist Nationalism." Foreign Affairs 68 (5):1-25. doi: 10.2307/20044197.

18. Bugajsky, Janusz. 1994. Ethnic Politics in Eastern Europe: A Guide to Nationality Policies. Armonk, N.Y: O.M.P. Sharpe.

19. Cappello, John. 05 April 2017. "Russia Escalates Disinformation Campaign in Western Balkans." www.defenddemocracy.org/media-hit/john-cappellorussia-escalates-disinformation-campaign-in-western-balkans/.

20. Cappello, John. 2017, 13 October. Russia Ramps Up Media and Military Influence in Balkans. Washington: Foundation for Defense of Democracies (FDD): http:// www.defenddemocracy.org/media-hit/john-cappello-russia-ramps-up-mediaand-military-influence-in-balkans/.

21. Castellan, Georges. 1999. Histoire des Balkans, XIV-XX Siècle. Paris: Fayard.

22. Cattaruzza, Amaël. 2008. "L'affirmation de I'Union européenne dans les Balkans. Vers une politique d'intégration régionale... mais de quelle région?" Strates: Matériaux pour la Recherche en Sciences Sociales 15 (http://journals. openedition.org/strates/6688).

23. Cleveland, Harlan. 1970. NATO: The Transatlantic Bargain. New York: Harper and Row.

24. Danopoulos, Costandine P., and Kostas G. Messas. 1997. "Ethnonationalism, Security and Conflict in the Balkans." In Crisis in the Balkans, Views from the Participants, edited by Costandine P. Danopoulos and Kostas G. Messas. Boulder, Co.: Westview Press. 
25. Davutoglu, Ahmet. 2008. "Turkey's Foreign Policy Vision: An Assessment of 2008." Insight Turkey 10 (1):77-96.

26. Demekas, Dimitri G., Balázs Horváth, Elina Ribakova, and Yi Wu. 2005. Foreign Direct Investment in Southeastern Europe: How (and how much) can policies help? IMF Working Paper WP/05/110 www.imf.org/external/pubs/ft/ wp/2005/wp05110.pdf.

27. Demirtas, Birgul. 2015. "Turkish Foreign Policy towards the Balkans: A Europeanized Foreign Policy in a De-europeanized National Context?" Journal of Balkan and Near Eastern Studies 17 (2):123-140.

28. Diamandouros, Nikiforos P. 1994. "Prospects for Democracy in the Balkans: Comparative and Theoretical Perspectives." In The Volatile Powder Keg, Balkan Security after the Cold War, edited by Stephen Larrabee, 3-26. Washington: The American University Press.

29. Dita, Gazeta. 2020, 22 March. Plani C dhe Plani D. http://www.gazetadita.al/ vetem-rama-nderron-qendrim-nese-bota-permbyset-kemi-turqine/.

30. Doja, Albert. 2001. "Démocratie et stabilité dans le Sud-Est européen. Facteurs humains, culturels et sociaux." Les Temps Modernes 59 (4/615-616):147-166. doi: 10.3917/ltm.615.0147.

31. Doja, Albert, and Enika Abazi. 2021. "The Mytho-Logics of Othering and Containment: Culture, Politics and Theory in International Relations." International Critical Thought 11 (1):130-155. doi: 10.1080/21598282.2021.1886145.

32. Đukanović, Milo. 2020, 8 April. edited by Twiter: https://twitter.com/i/ status/1247854322358128640.

33. Economist, The. 21 January 2016. "Mosqued objectives. Turkey is sponsoring Islam abroad to extend its prestige and power." https://www.economist.com/ news/europe/21688926-turkey-sponsoring-islam-abroad-extend-its-prestigeand-power-mosqued-objectives.

34. Estrin, S., and M. Uvalic. 2014. "FDI into transition economies." Economics of Transition 22 (2):281-312. doi: 10.1111/ecot.12040.

35. Estrin, Saul, and Milica Uvalic. 2016. "Foreign Direct Investment in the Western Balkans: What Role Has it Played During Transition?" Comparative Economic Studies 58 (3):455-483.

36. EURACTIV. 2020, 30 March. EU announces Covid-19 help for Balkans eastern neighbours after criticism. https://www.euractiv.com/section/eastern-europe/ news/eu-announces-covid-19-help-for-balkans-eastern-neighbours-aftercriticism/. 
37. European Commission. 2018. "A credible enlargement perspective for and enhanced EU engagement with the Western Balkans." https://ec.europa.eu/ commission/sites/beta-political/files/communication-credible-enlargementperspective-western-balkans_en.pdf.

38. European Commission. 2020, 25 March. Commission welcomes the green light to opening of accession talks with Albania and North Macedonia. Brussels: https://ec.europa.eu/commission/presscorner/detail/en/IP_20_519.

39. European Parliament. 30 April, 1998. Report on the role of the Union in the world: Implementation of the common foreign and security policy for 1997. edited by Security and Defense Policy Committee on Foreign Affairs. Brussels.

40. Fouéré, Erwan 29 October 2019. "Macron's "Non" to EU enlargement." Centre for European Policy Studies https://www.ceps.eu/macrons-non-to-euenlargement/.

41. Gadis, Karolos. 2018, 28 January. "Turkey's destabilizing role in the Balkans and South East Mediterranean area." Hellenic News, https://hellenicnews.com/ turkeys-destabilizing-role-balkans-south-east-mediterranean-area/.

42. Gagnon, V.P. 2004. The Myth of Ethnic War: Serbia and Croatia in the 1990s. Ithaca: Cornell University Press.

43. Giddens, Anthony. 1996. The Nation State and Violence. Cambridge: Polity Press.

44. Haas, Ernst B. 2004. The Uniting of Europe: Political, Social, and Economic Forces, 1950-1957. Notre Dame: University of Notre Dame Press. Original edition, 1958.

45. Haas, Richard N. 2008. "The age of Nonpolarity." Foreign Affairs, (MayJune):44-56.

46. Hayden, Robert. 1992. "Constitutional Nationalism in the Formerly Yugoslav Republics." Slavic Review 51 (4):654-673. doi: 10.2307/2500130.

47. Janjevic, Darko. 2017. "Erdogan wants Balkans as 'leverage' on Europe." Deutsche Welle, (www.dw.com/en/erdogan-wants-balkans-as-leverage-oneurope-expert/a-38009794).

48. Jelavich, Barbara. 1983. Balkan History. Vol. 1. Cambridge: Cambridge University Press.

49. Jesse, Neal G., and John R. Dreyer Jesse. 2016. Small States in the International System: At Peace and at War. Lanham: Lexington Books.

50. Jinping, Xi 2017. Report at 19th CPC National Congress. Beijing: Xinhua: www.xinhuanet.com/english/download/Xi_Jinping's_report_at_19th_CPC_ National_Congress.pdf. 
51. Kalotay, Kalman. 2010. "Patterns of Inward FDI in Economies in Transition." Eastern Journal of European Studies 1 (2):55-76.

52. Lampe, John R. 1990. "Southeastern Europe and the Legacy of Insecurity." In Problems of Balkan Security, Southeastern Europe in the 1990s, edited by John R. Lampe, 63-88. Washington, D.C.: The Wilson Centre Press.

53. Larrabee, Stephen. 1990. "Long memories and short fuses: change and instability in the Balkans." International Security 15 (3):58-91. doi: 10.2307/2538907.

54. Levitsky, Steven, and Lucan A. Way. 2005. "International Linkage and Democratization." Journal of Democracy 16 (3):20-34.

55. Marazopoulos, Christos 2013. "Constructing the Western Balkans: Understanding the European Commission's Regional Approach from A Constructivist Perspective." Ph.D. Thesis, Department of Politics, Languages and International Studies University of Bath.

56. Mathisen, Trygve. 1971. The Functions of Small States in the Strategies of the Great Powers. Oslo: Scandinavian University Books.

57. Mearsheimer, John J. 1990. "Back to the Future: Instability in Europe After the Cold War." International Security 15 (1):5-56.

58. Milica, Uvalić. 2019. "Economic Integration of the Western Balkans into the European Union: The Role of EU Policies." In The Europeanisation of the Western Balkans. New Perspectives on South-East Europe, edited by Keil S. Džankić J., Kmezić M. Cham: Palgrave Macmillan.

59. Mogherini, Federica. 6 March 2017. Remarks by the High Representative/VicePresident Federica Mogherini following the Foreign Affairs Council Brussels.

60. Moran, H. Theodore. 2014. Foreign Investment and Supply Chains in Emerging Markets: Recurring Problems and Demonstrate Solutions. Vol. WP 14-12, Working Paper Series. Washington D.C.: Peterson Institute for International Economics.

61. Mujanović, Jasmin, and Molly Montgomery. 31 October 2019. "Macron's Veto Leaves Balkans Wide Open for Russia and China." Foreign Policy.

62. Musaraj, A. (2019). Technocracy and the questionable moral philosophy of management. A Southeast Europe inside. Academicus International Scientific Journal, 10(19), 37-48.

63. Nevers, Renée de. 1993. "Democratization and Ethnic Conflict." In Ethnic Conflict and International Security, edited by Michael E. Brown, 61-76. Princeton, N.J.: Princeton University Press.

64. Osnos, Evan. 2018. "Making China Great Again. As Donald Trump surrenders America's global commitments, Xi Jinping is learning to pick up the pieces." 
The New Yorker. https://www.newyorker.com/magazine/2018/01/08/makingchina-great-again.

65. Pavlowitch, Stevan K. 1999. The Balkans, 1804-1945. London: Longman.

66. Poggetti, Lucrezia. 2017, 24 April. "China's Charm Offensive in Eastern Europe Challenges EU Cohesion." The Diplomat https://thediplomat.com/2017/11/ chinas-charm-offensive-in-eastern-europe-challenges-eu-cohesion/.

67. Rama, Edi. 5 December 2017. EU must marry Western Balkans quickly to avoid new risks. Brussels: Friends of Europe, https://www.euractiv.com/section/ enlargement/news/eu-must-marry-western-balkans-quickly-to-avoid-newrisks-albania-pm/.

68. Reuters. 2020, 3 Avril. "Russia sends medical aid to Serbia to fight coronavirus." https://www.reuters.com/article/us-health-coronavirus-russia-serbia/russiasends-medical-aid-to-serbia-to-fight-coronavirus-idUSKBN21L17H.

69. Richter, Solveig, and Natasha Wunsch. 2020. "Money, power, glory: the linkages between EU conditionality and state capture in the Western Balkans." Journal of European Public Policy 27 (1):41-62. doi: 10.1080/13501763.2019.1578815.

70. Sawyer, Jack. 1967. "Dimensions of Nations: Size, Wealth, and Politics." American Journal of Sociology 73 (2):145-172. doi: 10.1086/224457.

71. Schönfeld, Roland 1990. "Economic Challenges to the Communist States of Southeastern Europe." In Problems of Balkan security: Southeastern Europe in the 1990s, edited by Paul S. Shoup. Washington, D.C.: Wilson Center Press.

72. Secrieru, Stanislav. 2019. "Russia in the Western Balkans, Tactical wins, strategic setbacks." Geopolitical Series https://www.iss.europa.eu/content/ russia-western-balkans.

73. SGTN. 2020, 17 March. Serbia's state of emergency: 'China is the only country that can help'. https://youtu.be/P42OrsA045M?t=17.

74. Stein, Arthur A. 1980. "The Politics of Linkage." World Politics 33 (1):62-81. doi: $10.2307 / 2010255$.

75. Stronski, Paul, and Annie Himes. 2019. "Russia's Game in the Balkans." Washington D.C.: Carnegie Endowment for International Peace (https:// carnegieendowment.org/2019/02/06/russia-s-game-in-balkans-pub-78235).

76. The Economist. 15 May 2017. "What is China's belt and road initiative? The many motivations behind Xi Jinping's key foreign policy."

77. The Economist. 2017, 15 May. "What is China's belt and road initiative? The many motivations behind Xi Jinping's key foreign policy."

78. Todorova, Maria. 1997. Imagining the Balkans. 2nd ed. New York: Oxford University Press. Reprint, 2009. 
79. Tolstrup, Jakob. 2009. "Studying a negative external actor: Russia's management of stability and instability in the Near Abroad." Democratization 16 (5):922944. doi: 10.1080/13510340903162101.

80. Trade. 2017. "European Union, Trade in goods with Albania: http://trade. ec.europa.eu/doclib/docs/2006/september/tradoc_113342.pdf."

81. Trading Economics. 2018. "Albania Foreign Direct Investment 2004-2018." https://tradingeconomics.com/albania/foreign-direct-investment.

82. Treadway, John D. 1997. "Of Shatter Belts and Powder Kegs: A Brief Survey of Yugoslav History." In Crisis in the Balkans. Views from the Participants, edited by Constantine P. Danopoulos and Kostas G. Messas, 19-45. Boulder, Co.: Westview Press.

83. Weber, Max. 1978. Economy and Society: An Outline of Interpretative Sociology. Edited by Guenther Roth and Claus Wittich. Berkley: University of California Press.

84. Williams, Kristen P., Steven E. Lobell, and Neal G. Jesse. 2012. Beyond Great Powers and Hegemons: Why Secondary States Support, Follow, or Challenge. Stanford, CA: Stanford University Press.

85. Wood, Vincent. 2017, 18 April. "EU NIGHTMARE: Albania threatens Brussels 'give us membership or prepare for CHAOS'." Express. https://www.express. co.uk/news/world/793091/EU-Albania-membership-war-European-UnionBalkans-free-movement-Edi-Rama.

86. Xinhua. 2020, March 17. China sends first batch of medical aid to Serbia to help fight COVID-19. edited by http://en.people.cn/n3/2020/0317/c900009668981.html.

87. Yoruk, Murat-Ahmet. 2008, 16 April. "Perspektiva te reja ekonomike midis turqise dhe Shqiperise." Gazeta Shqiptare, www.balkanweb.com/site/ perspektiva-te-reja-ekonomike-midis-turqise-dhe-shqiperise/.

88. Zakaria, Fareed. 2008, 12 March. "The rise of the rest." Newsweek https:// fareedzakaria.com/columns/2008/05/12/the-rise-of-the-rest. 